\title{
High School Pre-Engineering Programs: Do They Contribute To College Retention?
}

Belinda Cole, Oklahoma State University, USA

Karen High, Oklahoma State University, USA

Kathryn Weinland, Oklahoma State University, USA

\begin{abstract}
The study examines the retention of students in the College of Engineering, Architecture and Technology at Oklahoma State University that enter college with a defined course sequence in a pre-engineering program from a regional career technology center as compared with the retention rates of university engineering students for the same time period. In addition to descriptive data, results from one-sample $\chi^{2}$ tests that compared the homogeneity of proportions in enrollment across semesters completed between the groups are presented. The results of this foundational study suggest similar rates of persistence in the College of Engineering, Architecture and Technology among Oklahoma regional technology center pre-engineering program students entering college and those entering with more traditional high school academic preparation.
\end{abstract}

Keywords: Pre-engineering; Persistence; Completion

\section{INTRODUCTION/CONCEPTUAL FRAMEWORK}

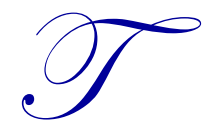

he problem of producing college graduates and especially engineers in the United States has been a topic documented in several reports and studies (National Academy of Science, 2007; Berkner, Cuccaro-Alamin, \& McCormick, 1996; Weiss, 2009). Today, much of everyday life in the United States and other industrialized nations, as evidenced in transportation, communication, agriculture, education, health and defense is the product of investments in research and in the education of scientists and engineers (Popper \& Wagner, 2002 as cited in Fantz, T.D., Sillera, T.J., \& Demiranda, M.A. 2011, p. 614). Within this discussion is a compounding problem of the inability to retain students in college, specifically colleges of engineering. An inability to maintain a healthy supply of trained engineers and scientists could negatively impact America's competitiveness in the global marketplace, which is, in the past, characterized by a continued dependence on knowledge in science and technology (Association for Career and Technical Education, 2009). According to the National Center for Educational Statistics (Wirt, J., Choy, S., Rooney, S., Rooney, P., Provasnik, S., Sen, A., \& Tobin, R. (2004), over 90 percent of the national 2002 high school sophomore cohort expected to attend college, with over 70 percent expecting to complete a four-year college degree. In actuality, 62 percent of the 2002 national sophomore cohort enrolled in college, and nearly half of these students failed to return for a second year. Despite efforts to enhance access to and success in college by aligning and improving curricula, this study and others (Wirt, J., Choy, S., Rooney, S., Rooney, P., Provasnik, S., Sen, A., \& Tobin, R. (2004) revealed that students who do not achieve successful college outcomes are disproportionately minority, low income, and first-generation college students (Snyder, T.D., \& Dillow, S.A., 2010).

While there is no definitive agreement on the exact percentage of freshman students who ultimately graduate with an engineering degree, this national number is estimated to range between 44 percent and 64 percent (Adelman, 1998; Huang, G., Taddese, N., \& Walter, E, 2000; Center for Institutional Data Exchange and Analysis, 2001; Berkner, Cuccaro-Alamin, \& McCormick, 1996; Ohland et al, 2008). It is generally accepted that there is a convergence of factors that lead to attrition. Program difficulty, lack of study skills, poor academic performance, quality instruction, and lack of knowledge about the skills needed to succeed in the engineering program are some of the factors that play a role in this phenomenon (National Academy of Engineering, 2011). Identifying those factors that influence retention should be useful in suggesting approaches to improving student success in engineering. The 
identification of these factors will assist in developing meaningful admission procedures as well as aid the counseling and advising of students seeking an engineering degree (Zhang, Anderson, Ohland, \& Thorndyke, 2004). The role of CTE STEM programs has not been examined extensively as a contributor toward engineering program retention. This is the major focus of this study.

Seymour and Hewitt (2000, p. 3) reported that students leaving engineering were academically no different than those that remained. They reported students left for reasons relating to perceptions of the institutional culture and career aspects.

\section{Redefining Career and Technical Education}

Career and technical education (CTE) has entered into a period of redefinition and reassessment of improving rigor and relevance to the $21^{\text {st }}$ Century knowledge and skills (Association for Career and Technical Education, 2009; Wakelyn, 2007; Brand, 2005; Medrich, Calderon, \& Hoachlander, 2003). Project Lead the Way (PLTW, 2011) has emerged as one of the leading efforts to engage middle and high school students in preengineering courses to provide a vehicle to raise the engagement of students in mathematics and science. PLTW also provides an avenue for students to explore the field of engineering in an integrated, project-based curriculum. PLTW is a national program with partners in public schools, colleges and universities, and the private sector. The project has developed a 4-year sequence of courses that, when combined with college preparatory mathematics and science, introduces students to the scope, rigor, career exploration, and discipline of engineering and engineering technology. Students participating in PLTW courses are better prepared for college engineering programs than those exposed only to the more traditional curricula (National Academy of Sciences, 2007, p. 128). The four-course sequence forms the foundation for a pre-engineering Plan of Study (POS) in CTE as the design model used in this study. In a study completed by Bottoms and Uhn (2007), 83 percent of PLTW students surveyed in the 2006 High Schools That Work national assessment said they planned to attend a two- or four-year college or university after they graduated, compared with 78 percent of CTE students from similar fields and 69 percent of CTE students from all fields. Attention to the need for more students to be engaged in science, technology, engineering, and mathematics (STEM) fields provides a natural connection to the redefinition of the mission and expectation of CTE programs in the United States.

Theodore Lewis (2007) makes the case with the new engineering education thrust, that career and technical education may be better positioned than traditional academic teachers to embrace the functioning and value of engineering in society. Further, he states that career and technical education has a greater affinity for engineering with the tradition of mechanical and craft education.

\section{Demand for STEM}

Two main factors are affecting the supply side of the STEM equation. First, the looming retirement of the baby boom generation will significantly affect the STEM labor force (National Academy of Sciences, 2007( for example, the number of current scientists and engineers retiring will increase rapidly over the next decade with twenty-six percent of people with science and engineering degrees currently working are 50 years or older. Second, too few students are currently choosing to prepare for STEM careers. From 1985 to 2005, the number of bachelor's degrees earned in engineering fell from to 77,572 to 66,133, and the number of associate degrees in engineering technology fell from 53,700 to 28,800 (National Science Board, 2008). In Oklahoma, seven out of every 1,000 individuals aged 18-24 received a bachelor's degree in natural sciences and engineering, placing Oklahoma in the $3^{\text {rd }}$ quartile nationwide (National Science Board, 2010). The State of Oklahoma decided to address the need to develop more engineers (Oklahoma Governor's Council for Workforce and Economic Development, 2007). Based on the analysis of the Aerospace Workforce Report, it is estimated that Oklahoma will likely experience shortages of approximately 200 Aerospace Engineers and 400 Electrical Engineers by 2014, with shortages of additional engineering specialties possible in that same time frame (Oklahoma Governor's Council for Workforce and Economic Development, 2007). Oklahoma CTE is embracing new technical areas such as pre-engineering to address the needs of business and industry as career and technical education is being charged with a re-design that embodies the spirit and letter of the Carl D. Perkins Vocational and Applied Technology Education Act, (2006). 


\section{Benefits of Diversity in Engineering}

There are also many benefits to diversity within the context of engineering teams. The members of the teams influence creativity in a group dynamic, so engineering teams that are more diverse can benefit creatively from the diversity (Wulf, 1998; Lane, 1999). Engineers can learn from each other, and a variety of perspectives lead to a higher quality of problem solving for all. This could be due to the increased critical thinking skills needed when viewing an issue from multiple viewpoints. The need for engineers to better relate to a changing population is also evident in the professional engineering workforce, which has lead to a need for a more diverse engineering workplace (Ihsen, 2005). The National Academy of Engineering $(2005 ; 2004)$ has also underscored the importance of diversity in engineering by making the recruitment of underrepresented populations one of many goals for the profession's future.

Several studies have also investigated the benefits of diversity in engineering environments. The main reason in support of a diverse engineering environment is that a more diverse engineering workforce can contribute to engineers having an increased ability to solve complex problems in new and creative ways (Schafer, 2006; Women in Engineering ProActive Network, 2009). The thought that diversity leads to more creative and improved ideas is also echoed by the Women in Engineering ProActive Network (WEPAN) (Women in Engineering ProActive Network, 2009). Teams that are more diverse are better equipped to meet the needs of a more diverse world, because the problem solving process is bolstered by the variety of perspectives and ideas that diversity brings.

\section{Retention}

Throughout the 1990s, fewer than half of undergraduate students who entered college intending to earn a science or engineering major completed a degree in one of those subjects (Berkner, Cuccaro-Alamin, \& McCormick, 1996; Smith, 2001). An NCES longitudinal study followed first-year students in 1990 that intended to complete a Science and Engineering (S\&E) major and found that fewer than half had completed an S\&E degree within 5 years. Approximately 20 percent of the students dropped out of college, and the others chose other fields (Huang, G., Taddese, N., \& Walter, E., 2000). The study also found that underrepresented minorities were more likely than students from other groups to drop out of S\&E programs. NCES did not collect data on students who moved into S\&E from other fields. A more recent study focused on 1993 freshmen with a declared S\&E major at 175 universities and colleges varying in size, selectivity, and highest degree level (Center for Institutional Data Exchange and Analysis, 2001). Like the NCES study, this study found that fewer than half of the students had completed an S\&E degree after 6 years. It also documented that women and underrepresented minorities left $S \& E$ programs at higher rates than men and nonminority students, resulting in lower degree completion rates for women and minorities. A feature of the STEM literature reviewed is the difference between the number of students initially declaring a STEM major and the number who have actually completed a STEM degree. Changing majors or dropping out of college altogether has been shown to be as high as 59 percent nationally for students who initially declared a STEM major (Daempfle 2003; Scott, Tolson, and Huang 2009; Tan 2002 as cited in LeBeau et al, 2012)

The Science and Engineering Indicators Report (National Science Board, 2008) found Science and Engineering (S\&E) students in U.S. universities persist and complete undergraduate programs at about the same rate as non-S\&E students. Six years after enrollment in a 4-year college or university in 1995-96, about 60 percent of both S\&E and non-S\&E students had completed a bachelor's degree. The overall retention rate at Oklahoma State University (OSU) used in this study reported a retention rate of 83.8 percent for new freshmen in 2008 for all majors and a six-year graduation rate for those entering in 2001 of 60.6 percent (Oklahoma State University, 2011). Undergraduate attrition may be due partly to a disconnection between the culture and curricula in high schools compared with those at colleges and universities. For example, poor mathematics preparation in high school may be an underlying issue contributing to attrition in undergraduate physics programs (Felder, Forrest, Ward, Dietz, \& Mohr, 1993). These types of problems suggest transitional programs or intentional career development to bridge the gap between high school and college may be indicated, but the value of such strategies have not been compared with those at other levels in the educational system. 
A study on college retention by engineering college majors (LeBeau, B., Harwell, M., Monson, D., Dupuis, D., Medhanie, A. \& Post, T.R., 2012) found no relationship between high-school mathematics curriculum and likelihood of completing a STEM major (Including engineering and mathematics majors). They further found that retention in college is not dependent on particular high-school characteristics such as location or whether a school offers more than a single mathematics option to its students. This finding provides support for the possible persistence and degree completion in college of pre-engineering students who take the engineering as well as science and math courses in a regional technology center. However, other studies such as Adelman ( 2005 ) indicates the opposite impact of core academic curriculum on college degree completion. Adelman (2005 states "The academic intensity of the student's high school curriculum still counts more than anything else in precollegiate history in providing momentum toward completing a bachelor's degree. These contradicting findings suggest more variables need to be examined which may lead to STEM degree completion. The quality rather than quantity math and science instruction was not considered in this large scale study.

An engineering persistence study by Burtner (2005) found that expectations and perceptions of the profession (specifically job outlook) and indicators of a student's self-confidence were the strongest predictors of status in engineering in years 1 and 3. However, relatively little is known about the factors that prompt students to complete (or not complete) a STEM major. A study conducted by O'Linn and Scott (2008), found that the students from their school who completed a high school pre-engineering program chose and completed an engineering program at a significantly higher rate than the national average. Though this is a small study it provides some encouraging evidence that high school pre-engineering programs may have an influence on STEM major selection and completion.

\section{CAREER AND TECHNICAL EDUCATION AND PROGRAMS OF STUDY}

In facing these serious challenges of Science, Technology, Engineering and Math (STEM) worker shortages, there is also reason for optimism in America's ability to ignite interest in STEM-related careers and strengthen the STEM literacy of the entire student population. The reason for that optimism stems from a growing level of STEM innovation that has evolved from the redesign of CTE nationally (Association for Career and Technology Education, 2009). CTE has long been engaged in pursuing integration of high-level academics and technology (Stone, Alfeld, Pearson, Lewis, \& Jensen, 2006). During the last decade literally thousands of new cutting-edge, STEM-intensive CTE programs have been launched or expanded in schools across the nation. Among them PLTW has expanded rapidly. As these programs move to larger-scale implementation, they have potential to help many additional students prepare for and pursue careers in STEM areas (Association for Career and Technology Education, 2009).

CTE programs and related initiatives provide key advantages in addressing the STEM challenge and securing America's leadership in innovation (Association for Career and Technology Education, 2009). CTE programs offer students a deeper understanding of STEM career pathways in order to facilitate student transitions into these areas, build interest in STEM and STEM-related careers by making math and science content more relevant and tangible to students through integration, and help grow the STEM workforce pipeline by encouraging more students from underrepresented populations to enter these career fields. According to a recent survey about teen attitudes toward STEM (Massachusetts Institute of Technology, 2009) students are exhibiting a renewed openness toward pursuing STEM professions and showing more interest in developing marketable STEM skills as the nation's economic future becomes more tenuous. However, the survey also indicates that youths' lack of understanding of STEM creates a serious obstacle. "Nearly two-thirds of teens indicated that they might be discouraged from pursuing a career in STEM because they do not know anyone who works in these fields (31 percent) or understand what people in these fields do ( 28 percent)."

CTE programs in pre-engineering, integrated with active career exploration and career advising, help students understand the breadth of careers that have a relationship to STEM and the varied pathways that can lead to those careers. STEM-intensive courses are being taught broadly in CTE through the use of definitive sequenced programs of study, an approach that gives students a broader understanding of the skills progression required for success in postsecondary education. If the PLTW strategy could be simplified to two components, they would be (1) maximize the pool of potential engineers by achieving proportional representation of all races, ethnicities, 
genders, and levels of affluence, and (2) maximize the success of PLTW students through effective program design and classroom instruction.

Through definitive pre-engineering programs, students can explore and then enter into a career pathway with knowledge and skills that theoretically will provide a better preparatory foundation between secondary and postsecondary education, and then into a high-skill, high-wage, high-demand job opportunity such as engineering. The pre-engineering model in Oklahoma also requires high-level math and science courses taken simultaneously with the pre-engineering courses (Oklahoma Department of Career and Technology Education, 2011).

\section{THEORETICAL FRAMEWORK}

Career development as it relates to greater confidence in selected STEM careers was used with a special focus on the stages Super labeled "growth" and "exploration." Super's theory and others (Lent, Brown, \& Hackett, 1994) agree that virtually all high school students are in the exploratory stage of their careers. Super's theory is an appropriate framework due to its capacity to address student needs at different stages and because it recognizes the need for intentional efforts toward career development over the life span. After its original publication, the theory has evolved in response to research and social changes, resulting in its most recent iteration in Super, Savickas, and Super (1996). Rojewski and Kim (2003) examined the occupational aspirations, vocational preparation, and work experiences of students planning to enter the workplace and those planning to enter college through longitudinal data gathered while the participants were in the 8th and 10th grades. They compared their findings with the sample's post-school transition activities (e.g., college or employment) and found that the individuals planning to enter the workforce had exhibited poorer academic performance, "had a higher sense of external locus of control, and had adopted lower level academic and occupational aspirations than their college-bound counterparts" (p. 102). Rojewski and Kim (2003) assert that these characteristics are "firmly established by grade 8" (p. 103). Furthermore, the gap between the college-bound group and those headed for the workforce widened through the $10^{\text {th }}$ grade. The importance of these data, as explained by the researchers, is that students are "pretty well 'locked in' to a particular orientation toward occupations and adult life early in their lives" (p. 104). Targeted career development interventions during the growth stage, as Super suggested, could widen the range of occupations compatible with children's emerging vocational self-concepts.

Another concept that undergirds the theoretical concept of this study is self-efficacy (Bandura, 1982). Selfefficacy is defined as "people's beliefs about their capabilities to produce designated levels of performance that exercise influence over events that affect their lives" (Bandura, 1994). Related to "perceived control, outcome expectations, perceived value of outcomes, attributions, and self-concept" (Schunk, 1991), it may have an effect on academic performance, as suggested in many studies (Bandura, 1994; Bong, 2003; Schunk, 1991; Zimmerman, 1992 as cited in Painter, S. \& Bates, R. (2012). Much of the current work done on self-efficacy can be attributed to Albert Bandura. In defining self-efficacy, Bandura stated four categories that are thought to be influencing factors: mastery experiences, social persuasion, vicarious experiences, and physiological state (Bandura, 1994). In a recent study, (Fantz, T.D., Sillera, T.J., \& Demiranda, M.A. 2011), the results suggest that more exposure to engineering content during the K-12 years is associated with a higher self-efficacy in engineering. This study provides greater insight into the types of exposure that are most related to higher self-efficacy in future engineering students. The formal experiences that produced the greatest differences in self-efficacy among students participating in the study were semester-long classes at the high school or middle-school level. In particular, students who participated in technology education classes and pre-engineering classes had significantly higher self-efficacy scores. Higher selfefficacy scores lead to better performance and persistence in engineering (Bandura 1977, 1997; Pajares, 1996 as cited in Fantz, T.D., Sillera, T.J., \& Demiranda, M.A. (2011). This results of this study suggest that participation in technology and pre-engineering classes should lead to higher student self-efficacy and therefore lower the attrition levels in engineering schools and increase the performance of students choosing to major in engineering. This study lends additional evidence for the contribution of career and technical education based pre-engineering to future collegiate degree completion. 


\section{PURPOSE AND RESEARCH QUESTIONS}

The purpose of the study was to establish a baseline for continued study examining the performance of students engaging in a defined pre-engineering program of study. The research questions for the study were:

1) To what extent do entering freshman students from pre-engineering programs at Oklahoma regional career technology centers persist in the Oklahoma State University College of Engineering, Architecture and Technology to complete a bachelor degree;

2) To what extent does participation in a defined pre-engineering program of study support students persisting in an engineering major at Oklahoma State University as compared to other engineering students?

\section{METHODOLOGY}

Graduating high school senior students completing a pre-engineering program of study at regional career technical centers in Oklahoma were administratively matched with engineering enrollment at Oklahoma State University. The factors of student name, high school, technology center, date entering the university, major, academic courses taken and last semester enrolled were collected and compared with university enrollment records. The study longitudinally followed students by name from fall 2005 through fall 2009 with a rolling cohort to determine persistence in the College of Engineering, Architecture and Technology (CEAT). The first year the program produced graduates matriculating to Oklahoma State University from a regional career and technical center using a defined and sequential program of study was 2005. The data collection for the 2005 cohort of students ended in 2009 for the purposes of this study. The intent is to continue this research annually as the number of entering freshmen from technology center pre-engineering programs grows. In 2005, only 5 PLTW students were identified at OSU when the study began. By 2009, the entering cohort had grown to 36 .

\section{RESULTS/FINDINGS}

The study compared enrollment trends for students enrolled in the OSU CEAT who had completed a Project Lead the Way (PLTW) program in high school with the general CEAT population.

A series of one-sample $\chi^{2}$ tests were performed to compare the homogeneity of proportions of students in the enrolled status across semesters between the PLTW and CEAT groups for each class.

Data were presented for the student cohorts that started their higher education in CEAT from fall 2005 to fall 2009. Students were classified at the end of each semester according to one of six enrollment statuses:

- $\quad$ Enrolled: Student is enrolled in CEAT

- $\quad$ Dropped: Student is no longer enrolled in OSU

- $\quad$ Enrolled Other: Student is enrolled in an OSU college other than CEAT

- $\quad$ Graduated: Student graduated from CEAT

- $\quad$ Graduated Other: Student graduated from an OSU college other than CEAT

The data were organized in sections corresponding to the six enrollment statuses. In each section, data for each enrollment status across completed semesters were analyzed by group (PLTW or CEAT) and cohort class. Data are presented as raw frequency enrollment counts and as counts normalized on the starting enrollment of the group.

The enrolled status indicates that a student was enrolled in CEAT for a semester. Data for the enrolled enrollment status across completed semesters are presented in Table 1. Enrollment starting sizes for CEAT have ranged from a low of 492 in 2008 to high 584 in 2009. PLTW group sizes represent from approximately $1 \%$ to $7 \%$ of the overall CEAT enrollment, ranging from a low of 5 in 2005 to a high of 34 in 2009. 
Table 1

Enrolled by Semesters Completed

\begin{tabular}{|c|c|c|c|c|c|c|c|c|c|c|c|}
\hline \multirow[b]{2}{*}{ Class } & \multirow{2}{*}{$\begin{array}{c}\text { Group } \\
\text { Size }\end{array}$} & \multicolumn{10}{|c|}{ Semesters Completed } \\
\hline & & 1 & 2 & 3 & 4 & 5 & 6 & 7 & 8 & 9 & 10 \\
\hline \multirow[t]{4}{*}{2005} & CEAT & 443 & 343 & 305 & 284 & 280 & 269 & 264 & 209 & 145 & 54 \\
\hline & 584 & 75.9 & 58.7 & 52.2 & 48.6 & 47.9 & 46.1 & 45.2 & 35.8 & 24.8 & 9.2 \\
\hline & PLTW & 5 & 3 & 1 & 1 & 0 & 0 & 1 & 1 & 1 & 1 \\
\hline & 5 & 100.0 & 60.0 & 20.0 & 20.0 & .0 & .0 & 20.0 & 20.0 & 20.0 & 20.0 \\
\hline \multirow{4}{*}{2006} & CEAT & 429 & 327 & 294 & 265 & 259 & 253 & 244 & 186 & & \\
\hline & 514 & 83.5 & 63.6 & 57.2 & 51.6 & 50.5 & 49.2 & 47.4 & 36.2 & & \\
\hline & PLTW & 12 & 9 & 9 & 10 & 10 & 9 & 9 & 9 & & \\
\hline & 15 & 80.0 & 60.0 & 60.0 & 66.7 & 66.7 & 60.0 & 60.0 & 60.0 & & \\
\hline \multirow{4}{*}{2007} & CEAT & 439 & 328 & 295 & 273 & 267 & 263 & & & & \\
\hline & 504 & 87.1 & 65.1 & 58.5 & 54.2 & 53.0 & 52.2 & & & & \\
\hline & PLTW & 21 & 18 & 15 & 14 & 13 & 13 & & & & \\
\hline & 26 & 80.8 & 69.2 & 57.5 & 53.8 & 50.0 & 50.0 & & & & \\
\hline \multirow[t]{4}{*}{2008} & CEAT & 413 & 315 & 290 & 279 & & & & & & \\
\hline & 492 & 83.9 & 64.0 & 58.9 & 56.7 & & & & & & \\
\hline & PLTW & 29 & 21 & 16 & 14 & & & & & & \\
\hline & 32 & 90.6 & 65.6 & 50.0 & 43.8 & & & & & & \\
\hline \multirow[t]{4}{*}{2009} & CEAT & 469 & 393 & & & & & & & & \\
\hline & 544 & 86.2 & 72.2 & & & & & & & & \\
\hline & PLTW & 32 & 23 & & & & & & & & \\
\hline & 36 & 86.5 & 62.2 & & & & & & & & \\
\hline
\end{tabular}

The enrolled counts across semester for the CEAT group were used as the hypothesized proportions. Results of the tests are presented in Table 2. Test results indicated non-significant $\chi^{2}$ for all cases, indicating the enrolled proportions are the same across semesters for both groups. Test could not be performed for 2005 class because some data cells had zero observations.

Table 2

Enrollment Homogeneity of Proportions (PLTW vs. CEAT Hypothesized)

\begin{tabular}{ccccc}
\hline Class & $\boldsymbol{\chi}^{2}$ & $\boldsymbol{N}$ & $\boldsymbol{d}$ & $\boldsymbol{p}$ \\
\hline 2005 & $* *$ & & & \\
2006 & 2.807 & 92 & 6 & .946 \\
2007 & .224 & 120 & 4 & 1.000 \\
2008 & 1.456 & 112 & 2 & .834 \\
2009 & .398 & 92 & 2 & .819 \\
\hline
\end{tabular}

Note: ** Two cells had 0 observations

\section{Dropped}

The dropped status indicates that a student no longer enrolled at OSU for a semester. Data for the dropped enrollment status across completed semesters are presented in Table 3.

In general, analyses indicate normalized dropped enrollment for both groups tends to rise quickly after the first and second semesters and then stabilizes with a slight decline for the remaining semesters. As with the enrolled status, the normalized dropped data from semester to semester for the PLTW group exhibited more variance than the CEAT group due to the small group size.

A series of one-sample $\chi^{2}$ tests were performed to compare the homogeneity of proportions of students in the dropped status across semesters between the PLTW and CEAT groups for each class. The dropped counts across semester for the CEAT group were used as the hypothesized proportions. Results of the tests are presented in Table 4. Test results indicated non-significant $\chi^{2}$ for all cases, indicating the dropped proportions are the same across semesters for both groups. Test could not be performed for the 2005 class because some data cells had zero observations. In addition, cases for classes from 2006 to 2008 had some cells that had less than 5 observations, so results should be interpreted with caution. 
Table 3

Dropped by Semester Completed

\begin{tabular}{|c|c|c|c|c|c|c|c|c|c|c|c|}
\hline \multirow[b]{2}{*}{ Class } & \multirow{2}{*}{$\begin{array}{c}\text { Group } \\
\text { Size }\end{array}$} & \multicolumn{10}{|c|}{ Semesters Completed } \\
\hline & & 1 & 2 & 3 & 4 & 5 & 6 & 7 & 8 & 9 & 10 \\
\hline \multirow[t]{4}{*}{2005} & CEAT & 41 & 114 & 134 & 150 & 160 & 155 & 157 & 159 & 167 & 169 \\
\hline & 584 & 7.0 & 19.5 & 22.9 & 25.7 & 27.4 & 26.5 & 26.9 & 27.2 & 28.6 & 28.9 \\
\hline & PLTW & 0 & 1 & 2 & 2 & 2 & 3 & 4 & 3 & 3 & 3 \\
\hline & 5 & .0 & 20.0 & 40.0 & 40.0 & 40.0 & 60.0 & 80.0 & 60.0 & 60.0 & 60.0 \\
\hline \multirow[t]{4}{*}{2006} & CEAT & 34 & 84 & 103 & 126 & 134 & 142 & 149 & 152 & & \\
\hline & 514 & 6.6 & 16.3 & 20.0 & 24.5 & 26.1 & 27.6 & 29.0 & 29.6 & & \\
\hline & PLTW & 1 & 3 & 4 & 3 & 3 & 4 & 4 & 4 & & \\
\hline & 15 & 16.7 & 20.0 & 26.7 & 20.0 & 20.0 & 26.7 & 26.7 & 26.7 & & \\
\hline \multirow[t]{4}{*}{2007} & CEAT & 30 & 104 & 126 & 137 & 142 & 144 & & & & \\
\hline & 504 & 6.0 & 20.6 & 25.0 & 27.2 & 28.2 & 28.6 & & & & \\
\hline & PLTW & 2 & 5 & 6 & 5 & 6 & 8 & & & & \\
\hline & 26 & 7.7 & 19.2 & 23.1 & 19.2 & 23.1 & 30.8 & & & & \\
\hline \multirow[t]{4}{*}{2008} & CEAT & 37 & 95 & 114 & 131 & & & & & & \\
\hline & 492 & 7.5 & 19.3 & 23.2 & 26.6 & & & & & & \\
\hline & PLTW & 2 & 8 & 13 & 16 & & & & & & \\
\hline & 32 & 6.3 & 25.0 & 40.6 & 50.0 & & & & & & \\
\hline \multirow[t]{4}{*}{2009} & CEAT & 39 & 101 & & & & & & & & \\
\hline & 544 & 7.2 & 18.6 & & & & & & & & \\
\hline & PLTW & 4 & 14 & & & & & & & & \\
\hline & 36 & 10.8 & 37.8 & & & & & & & & \\
\hline
\end{tabular}

Note: Percentages based on starting group size are presented in italicized font.

Table 4

Dropped Homogeneity of Proportions (PLTW vs. CEAT Hypothesized)

\begin{tabular}{ccccc}
\hline Class & $\boldsymbol{\chi}^{2}$ & $\boldsymbol{N}$ & $\boldsymbol{d}$ & $\boldsymbol{p}$ \\
\hline 2005 & $* *$ & & & \\
2006 & $.860^{*}$ & 26 & 7 & .997 \\
2007 & $.904^{*}$ & 32 & 5 & .970 \\
2008 & $1.778^{*}$ & 39 & 3 & .620 \\
2009 & .284 & 18 & 1 & .594 \\
\hline
\end{tabular}

Note: * Some cells had less than 5 observations.

** One cell had 0 observations.

\section{Enrolled Other}

The enrolled other status indicates that a students are enrolled in an OSU college other than CEAT for a semester. Data of other enrollments across completed semesters are presented in Table 5.

In general, the analyses show normalized enrolled other for both groups tends to rise quickly after the first and second semesters and then stabilizes with a slight decline for the remaining semesters. As with the enrolled and dropped statuses, the normalized data from semester to semester for the PLTW group exhibited more variance than the CEAT group due to the small group size.

A series of one-sample $\chi^{2}$ tests were performed to compare the homogeneity of proportions of students in the enrolled other status across semesters between the PLTW and CEAT groups for each class. The enrolled other counts across semester for the CEAT group were used as the hypothesized proportions. Results of the tests are presented in Table 6. 
Table 5

Enrolled Other by Semesters Completed

\begin{tabular}{|c|c|c|c|c|c|c|c|c|c|c|c|}
\hline \multirow[b]{2}{*}{ Class } & \multirow{2}{*}{$\begin{array}{c}\text { Group } \\
\text { Size }\end{array}$} & \multicolumn{10}{|c|}{ Semesters Completed } \\
\hline & & 1 & 2 & 3 & 4 & 5 & 6 & 7 & 8 & 9 & 10 \\
\hline \multirow{4}{*}{2005} & CEAT & 100 & 127 & 145 & 150 & 144 & 156 & 156 & 87 & 65 & 28 \\
\hline & 584 & 17.1 & 21.7 & 24.8 & 25.7 & 24.7 & 26.7 & 26.7 & 14.9 & 11.1 & 4.8 \\
\hline & PLTW & 0 & 1 & 2 & 2 & 2 & 2 & 1 & 1 & 1 & 0 \\
\hline & 5 & .0 & 20.0 & 40.0 & 40.0 & 40.0 & 40.0 & 20.0 & 20.0 & 20.0 & .0 \\
\hline \multirow{4}{*}{2006} & CEAT & 51 & 103 & 117 & 123 & 121 & 116 & 114 & 85 & & \\
\hline & 514 & 9.9 & 20.0 & 22.8 & 23.9 & 23.5 & 22.6 & 22.2 & 16.5 & & \\
\hline & PLTW & 2 & 3 & 2 & 2 & 2 & 2 & 2 & 1 & & \\
\hline & 15 & 13.3 & 20.0 & 13.3 & 13.3 & 13.3 & 13.3 & 13.3 & 6.7 & & \\
\hline \multirow{4}{*}{2007} & CEAT & 35 & 72 & 83 & 94 & 95 & 97 & & & & \\
\hline & 504 & 6.9 & 14.3 & 16.5 & 18.7 & 18.8 & 19.2 & & & & \\
\hline & PLTW & 3 & 3 & 5 & 7 & 7 & 5 & & & & \\
\hline & 26 & 11.5 & 11.5 & 19.2 & 26.9 & 26.9 & 19.2 & & & & \\
\hline \multirow{4}{*}{2008} & CEAT & 42 & 82 & 88 & 82 & & & & & & \\
\hline & 492 & 8.5 & 16.7 & 17.9 & 16.7 & & & & & & \\
\hline & PLTW & 1 & 3 & 3 & 2 & & & & & & \\
\hline & 32 & 3.1 & 9.4 & 9.4 & 16.3 & & & & & & \\
\hline \multirow{4}{*}{2009} & CEAT & 36 & 50 & & & & & & & & \\
\hline & 544 & 6.6 & 9.2 & & & & & & & & \\
\hline & PLTW & 1 & 0 & & & & & & & & \\
\hline & 36 & 2.7 & .08 & & & & & & & & \\
\hline
\end{tabular}

Test results indicated non-significant $\chi^{2}$ for all cases that could be run, indicating the enrolled other proportions are the same across semesters for both groups. Test could not be performed for the 2005 class because some cells had zero observations. Cases for classes from 2006 to 2008 had some cells that had less than 5 observations, so results should be interpreted with caution. No analysis was run for the 2009 class because only a single category was present.

Table 6

Enrolled Other Homogeneity of Proportions (PLTW vs. CEAT Hypothesized)

\begin{tabular}{ccccc}
\hline Class & $\boldsymbol{\chi}^{2}$ & $\boldsymbol{N}$ & $\boldsymbol{d} \boldsymbol{p}$ & $\boldsymbol{p}$ \\
\hline 2005 & $* *$ & & & \\
2006 & $1.996^{*}$ & 16 & 5 & .960 \\
2007 & $1.387^{*}$ & 30 & 3 & .926 \\
2008 & $.298^{*}$ & 9 & 3 & .960 \\
2009 & $* * *$ & & & \\
\hline
\end{tabular}

Note: * Some cells had less than 5 observations,

** One cell had 0 observations,

*** Only 1 case present

\section{Graduated}

The graduated status indicates that a student graduated from CEAT in the semester. Data for the graduated enrollment status across completed semesters are presented in Table 7. Comparisons were not made between groups because no PLTW students had yet graduated from CEAT. 
Table 7

Graduated by Semester Completed

\begin{tabular}{|c|c|c|c|c|c|c|}
\hline \multirow[b]{2}{*}{ Class } & \multirow{2}{*}{$\begin{array}{c}\text { Group } \\
\text { Size }\end{array}$} & \multicolumn{5}{|c|}{ Semesters Completed } \\
\hline & & 6 & 7 & 8 & 9 & 10 \\
\hline \multirow{4}{*}{2005} & CEAT & 0 & 2 & 54 & 111 & 202 \\
\hline & 584 & .0 & .3 & 9.2 & 19.0 & 34.6 \\
\hline & PLTW & 0 & 0 & 0 & 0 & 0 \\
\hline & 5 & .0 & .0 & .0 & .0 & .0 \\
\hline \multirow{4}{*}{2006} & CEAT & 1 & 2 & 56 & & \\
\hline & 514 & 0.2 & 0.4 & 10.9 & & \\
\hline & PLTW & 0 & 0 & 0 & & \\
\hline & 15 & .0 & .0 & .0 & & \\
\hline
\end{tabular}

\section{Graduated Other}

The graduated other status indicates that a student graduated from an OSU college other than CEAT in the semester. Data for the graduated other enrollment status across completed semesters are presented in Table 8. No comparisons were made between groups because only one PLTW students has graduated from an OSU college other than CEAT.

Table 8

Graduated Other by Semester Completed

\begin{tabular}{|c|c|c|c|c|c|c|}
\hline \multirow[b]{2}{*}{ Class } & \multirow{2}{*}{$\begin{array}{c}\text { Group } \\
\text { Size }\end{array}$} & \multicolumn{5}{|c|}{ Semesters Completed } \\
\hline & & 6 & 7 & 8 & 9 & 10 \\
\hline \multirow{4}{*}{2005} & CEAT & 4 & 5 & 75 & 96 & 131 \\
\hline & 584 & .7 & .9 & 12.8 & 16.4 & 22.4 \\
\hline & PLTW & 0 & 0 & 0 & 0 & 1 \\
\hline & 5 & .0 & .0 & .0 & .0 & 20.0 \\
\hline \multirow{4}{*}{2006} & CEAT & 2 & 5 & 35 & & \\
\hline & 514 & 0.4 & 1.0 & 6.8 & & \\
\hline & PLTW & 0 & 0 & 1 & & \\
\hline & 15 & .0 & .0 & 6.7 & & \\
\hline
\end{tabular}

\section{Graduated}

The graduated status indicates that a student graduated from CEAT in the semester. Data for the graduated enrollment status across completed semesters are presented in Table 9. Comparisons were not made between groups because no PLTW students had yet graduated from CEAT.

Table 9

Graduated by Semester Completed

\begin{tabular}{|c|c|c|c|c|c|c|}
\hline \multirow[b]{2}{*}{ Class } & \multirow{2}{*}{$\begin{array}{c}\text { Group } \\
\text { Size }\end{array}$} & \multicolumn{5}{|c|}{ Semesters Completed } \\
\hline & & 6 & 7 & 8 & 9 & 10 \\
\hline \multirow{4}{*}{2005} & CEAT & 0 & 2 & 54 & 111 & 202 \\
\hline & 584 & .0 & .3 & 9.2 & 19.0 & 34.6 \\
\hline & PLTW & 0 & 0 & 0 & 0 & 0 \\
\hline & 5 & .0 & .0 & .0 & .0 & .0 \\
\hline \multirow{4}{*}{2006} & CEAT & 1 & 2 & 56 & & \\
\hline & 514 & 0.2 & 0.4 & 10.9 & & \\
\hline & PLTW & 0 & 0 & 0 & & \\
\hline & 15 & .0 & .0 & .0 & & \\
\hline
\end{tabular}

Trends for the enrollment statuses of enrolled, dropped, and enrolled other for both the CEAT and PLTW groups showed a general trend of a rapid change in the first two years followed by stabilization with a smaller number for the remaining semester of a student career. The small size of the PLTW group relative to the general CEAT population (less than 7\%) manifests itself in more variance in the PLTW normalized enrollments for the different statuses, so comparisons of the groups based on normalized data need to be cautiously interpreted. In 
general, the analyses show normalized dropped enrollment for both groups tends to rise quickly after the first and second semesters and then stabilizes with a slight decline for the remaining semesters.

One-sample $\chi^{2}$ tests showed that the proportions of the enrolled status are the same for both groups for most classes that had adequate observations to perform the tests. Similar conclusions were drawn from chi-square tests for the dropped and enrolled other status, but many of the classes had cell sizes of less than recommended minimal size, so the results need to be interpreted with caution. In general, these data indicated that the PLTW and CEAT groups had had similar enrollment patterns over the 5 years from 2005 to 2009 , with neither group exhibiting a significant advantage or disadvantage.

\section{CONCLUSIONS AND DISCUSSION}

While this study is limited to a pre-engineering program of study in Oklahoma regional career technology centers, findings suggest that completing a pre-engineering program of study, with both academic and technical courses, may have a positive impact on enrollment and persistence in OSU CEAT degree programs with students who may be arriving at University differently prepared than traditional engineering students. Traditionally, engineering students have a high school course-taking pattern of advanced science and mathematics courses. In this early cohort of Pre-engineering students from Oklahoma regional career technology centers had taken the sequence of three mathematics courses and three lab-science courses required by the state for college entrance, but may not have completed Advanced Placement or Calculus courses before entering the university. The intent of the Preengineering programs at Oklahoma regional technology centers is to engage and challenge average students through experiential learning in engineering and encourage taking advanced math and science courses as part of a strong preparation program for university degree completion. Pre-engineering students from Oklahoma regional career technology centers appear to persist at OSU at a similar rate than general students in CEAT. This average retention rate of CEAT students is consistent with national estimates (Adelman, 1998; Huang, G., Taddese, N., \& Walter, E., 2000; Center for Institutional Data Exchange and Analysis, 2001; Berkner \& Cuccaro-Alamin, 1996; Ohland et al, 2008).

Additional research is needed to compare OSU students entering from Oklahoma regional career technology centers with engineering students in general to determine whether a POS makes a difference in persistence and performance. In addition, an examination of other state universities attended by the pre-engineering students from regional technology centers should be examined to determine if the patterns found in this study may be similar in other state institutions with Engineering majors. Additional data from other states should be examined for effects on postsecondary enrollment and persistence to begin to build a body of research on the effects of PLTW related to persistence in University College of Engineering Programs.

According to True Outcomes Assessment (Walcerz, 2007) PLTW courses attract a much more diverse population than engineering programs in colleges and universities. However, the current study did not examine the gender or ethnicity of the 2005-2009 PLTW Oklahoma cohorts nor were comparisons made to CEAT. True Outcomes is a national assessment of PLTW so this data may be used for more extensive study of the characteristics of PLTW students as compared to more traditional engineering students. If the True Outcomes findings is indeed reflective of Oklahoma data, then the fact that retention of the PLTW students in the college of engineering is virtually the same may be in fact significant if the cohort represents a more diverse body of students. Additional study is also needed to examine the variables of race and gender

Fantz, Siller, and Demaranda (2011 p.614) found significant differences in self-efficacy were only found between groups of students who had pre-engineering classes and engineering hobbies versus students who did not have these experiences. Having experiences in engineering pre-college appears to have an impact on student's belief in their ability to do the work of engineers in college. Though self-efficacy was not investigated in this study, the fact that only those students who had pre-engineering classes or other experiences in engineering had higher selfefficacy could reveal another indicator that students who have these experiences may have similar successes in college than those traditionally prepared with intense math and science coursework. As Seymour and Hewitt (2000, p. 3) found that students who left engineering did not leave due to academic ability but culture and career perception. It is important to consider the role of career exploration in persistence in engineering. 
Care must be taken to interpret these data as PLTW having impact on the rate of engineering graduates based on this study. Further study is needed to examine composition of gender and ethnicity in Oklahoma PLTW programs and the rate of persistence and degree completion by gender and ethnicity to determine if PLTW may be contributing to an improvement in these rates. Investigation is also needed to probe the role of career development in retention of these students as suggested in the literature reviewed.

\section{AUTHOR INFORMATION}

Belinda Cole, Oklahoma State University. Associate Professor and Tuttle Endowed Chair for Occupational Education Studies in the College of Education., School of Teaching and Curriculum Leadership. E-mail: belinda.cole@okstate.edu (Corresponding author)

Karen High, Oklahoma State University. Associate Professor, Chemical Engineering, College of Engineering, Architecture, and Technology. E-mail: karen.high@,okstate.edu

Kathryn Weinland, Oklahoma State University._Lecturer, Speech Communications, Department of Psychology. E-mail: kathryn.weinland@okstate.edu

\section{REFERENCES}

1. United States. National Center for Improving Science Education. Women and men of the engineering path: A model for analyses of undergraduate careers. Washington: GPO, 1998. Print.

2. Association for Career and Technical Education (2009). ACTE Issue brief: CTE's role in science, technology, engineering \& math. Alexandria, VA: Author.

3. United States. Commission on Professionals in Science and Technology. Trends in African American and Native American participants in STEM higher education. Washington: GPO, 2002. Print.

4. Adelman, C. (2005). The Toolbox Revisited: Paths to Degree Completion from High School Through College. The Journal for Vocational Special Needs Education. Volume 28, Number 1.

5. Berkner, Lutz K, Cuccaro-Alamin, Stephanie, and McCormick, Alexander C. Descriptive summary of 1989-90 beginning postsecondary students: 5 years later with an essay on postsecondary persistence and attainment. Washington: National Center for Education Statistics, 1996. Print.

6. Bottoms, Gene and Uhn, John. Project Lead The Way® works: A new type of career and technical program. Atlanta, GA: Southern Regional Education Board, 2007. Print.

7. Brand, Betsy. "What a 21st Century Career and Technical System Could Look Like." Remaking Career and Technical Education for the 21st Century, ed. Kazis. Boston: Jobs for the Future, 2005. (pg. 26-28). Print.

8. Burtner, Joan. "The use of discriminant analysis to investigate the influence of noncognitive factors on engineering school persistence." Journal of Engineering Education, 94.3 (2005): 335. Print.

9. Carl D. Perkins Vocational and Applied Technology Education Act, 20 U.S.C. $\$ 2301$ et seq. (2006). Retrieved 21 September 2011 from LexisNexis Academic database. PL109-270

10. Center for Institutional Data Exchange and Analysis. 1999-2000 SMET retention report. Norman: University of Oklahoma, 2001. Print.

11. Fantz, Todd, Siller, Thomas and Demarinda, Michael A. "Pre-collegiate factors influencing the selfefficacy of engineering students." Journal of Engineering Education 100.3, (2011): 604-623.

12. Felder, Richard, Forrest, Krista, Ward, Lynne Baker, Dietz, E. Jacqulin, and Mohr, Phyllis H.. “A longitudinal study of engineering student performance and retention: I. success and failure in the introductory course. " Journal of Engineering Education, 82.1 (1993): 15-21.

13. Gibbons, Michael T. (2009). Engineering by the numbers. Washington, DC: American Society for Engineering Education: Profiles of Engineering and Engineering Technology Colleges. (2009). Web. http://www.asee.org/papers-and-publications/publications/college-profiles/2010-profile-engineeringstatistics.pdf

14. Huang, Gary, Taddese, Nebiyu, and Walter, Elizabeth. Entry and Persistence of Women and Minorities in College Science and Engineering Education. Washington: National Center for Educational Statistics, 2000. Print. 
15. Ihsen, Susanne. "Special gender studies for engineering?" European Journal of Engineering Education, 30.4 (2005): 487-494.

16. Lane, Neal. "Increasing diversity in the engineering workforce." The Bridge, 29.2 (1999): 15-19.

17. LeBeau, Brandon, Harwell, Michael, Monson, Debra Dupuis, Danielle, Medhanie, Amanuel and Post, Thomas R. "Student and high-school characteristics related to completing a science, technology, engineering or mathematics (STEM) major in college." Research in Science and Technological Education, 30.1 (2012): 17-28.

18. Lent, Robert W., Brown, Steven D., and Hackett, Gail. "A social cognitive view of career development and counseling." Career Choice and Development, eds. Brown and Brooks, San Francisco, CA: Jossey-Bass, 1994. (101-130). Print.

19. Lewis, T. Engineering education. International Journal of Engineering Education, 5.1 (2007): 843-252.

20. Massachusetts Institute of Technology. Survey: majority of U.S. teens feel prepared for careers in science, technology, engineering and mathematics, yet many lack mentors. Massachusetts Institute of Technology. (2009).Press Release. 174.

21. May, Gary S., Chubin, Daryl E., Babco, Eleanor L.. "Diversifying the engineering workforce." Journal of Engineering Education, 94.1 (2005): 73-86.

22. Medrich, Elliott, Calderon, Sarah, and Hoachlander, Gary. "Contextual Teaching and Learning Strategies in High Schools: Developing a Vision for Support and Evaluation", Essential Forms of High School Reform: New Forms of Assessment and Contextual Teaching and Learning, Ed. Betsy Brand, Washington: American Youth Policy Forum, (2003). 35-77. Print.

23. National Academy of Engineering. Factors Contributing to High Attrition Rates Among Science and Engineering Undergraduate Majors (Index of Abstracts). 2011. Online Ethics Center for Engineering. Web. www.onlineethics.org/Topics/Diversity/DiverseEssays/Abstracts/attrition.aspx

24. National Academy of Engineering. Educating the Engineer of 2020: Adapting Engineering Education to the New Century. Washington, DC: The National Academies Press, 2005.

25. National Academy of Engineering. The engineer of 2020: Vision of engineering in the new century. Washington, DC: The National Academies Press, 2004.

26. National Academy of Sciences. Rising above the gathering storm: Energizing and employing America for a brighter economic future. 2007. Web. http://www.nap.edu/catalog/11463.html

27. National Science Board. Science and engineering indicators 2010. Arlington, VA: National Science Foundation (NSB 10-01). (2010): Web. (NSB 10-01). http://www.nsf.gov/statistics/seind10/c8/c8s2o16.htm

28. National Science Board. Science and engineering indicators 2008. Arlington, VA: National Science Foundation (NSB 08-01A). (2008): Print.

29. Science Technology and Math Division. Oklahoma Department of Career and Technical Education, (2011). Web. http://www.okcareertech.org/stem/index.htm

30. Ohland, Michael, Sheppard, Sheri D., Lichtenstein, Gary, Eris, Ozgar, Chachra, Debbie, and Layton, Richard A., "Persistence, engagement, and migration in engineering programs. "Journal of Engineering Education, 97.3 (2008): 259-278.

31. Oklahoma Governor's Council for Workforce and Economic Development, (2007). Oklahoma's aerospace industry workforce: 2007 report. Oklahoma City, OK: Oklahoma Department of Commerce.

32. Oklahoma State University, (2011). Fall 2010 student profiles, Institutional Research and Information Management. Retrieved from http://vpaf.okstate.edu/irim/StudentProfileDownload.html

33. O’Linn, Frank W., Scott, Mary Ellen. (2008). "Evaluating the impact of the St. Edward high school preengineering program on successful collegiate engineering study." Web. http://ace.nd.edu/actionresearch/evaluating-the-impact-of-the-st-edward-high-school-pre-engineering-program-on-successfulcollegiate-engineering-study

34. Painter, Sarah and Bates, Rebecca. "Statistical models of self-efficacy in STEM students." Journal of Undergraduate Research (2012): Print.

35. PLTW. Project lead the way overview. Retrieved from http://www.pltw.org/educators-administrators/ourprograms. (2011). Web.

36. Pointon, Michael, Edmister, Julie Horne), Ukeiley, Lawrence and Seiner, John M.. "Understanding the role of self-efficacy in engineering education.” Journal of Engineering Education, 90.2 (2001): 247-251. 
37. Rojewski, Jay and Kim, Heeja. "Career choice patterns and behavior of work-bound youth during early adolescence.” Journal of Career Development, 30.2 (2003): 89-108. Print.

38. Schafer, Andrea. "A new approach to increasing diversity in engineering at the example of women in engineering." European Journal of Engineering Education, 31.6 (2006): 661-671.

39. Seymour, Elaine and Hewitt, Nancy M.. Talking about leaving: Why undergraduates leave the sciences. Boulder, CO: Westview Press, 2000. Print.

40. Smith, T. The retention and graduation rates of 1993-1999 entering science, mathematics, engineering, and technology majors in 175 colleges and universities. Norman, OK: University of Oklahoma Center for Institutional Data Exchange and Analysis, 2001. Print.

41. Snyder, Thomas A. and Dillow, Sally A. Digest of education statistics. Washington, DC: NCES, 2010. Web. http://nces.ed.gov/programs/digest/d10/tables/dt10 341.asp

42. Stone, James R., Alfeld, Corinne, Pearson, Donna, Lewis, Morgan, and Jensen, Susan. Building academic skills in context: Testing the value of enhanced math learning in CTE (Final report). Minneapolis, MN: University of Minnesota National Research Center for Career and Technical Education, 2006. Print.

43. Super, Donald E., Savickas, Mark, and Super, Charles M.. (1996). The life span, life-space approach to careers. Eds. Duane Brown and Linda Brooks. Career choice and development. San Francisco, CA: Jossey-Bass, 1996. Print.

44. Super, Donald E. (1990). A life span, life-space approach to career development. Eds. D Brown, Linda Brooks, and Associates. Career choice and development: Applying contemporary theories in practice. Francisco: Jossey-Bass, 1990: Print.

45. Wakelyn, David. Retooling career and technical education. Washington, DC: NGA Center for Best Practices National Governor's Association, 2007. Print.

46. Walcerz, Douglas. Report on the Third Year of Implementation of the True Outcomes Assessment System for Project Lead The Way. 2007: Web. http://www.eweek.org/site/pdfs/Report\%20on\%20third\%20Year\%20Implementation.pdf

47. Weiss, Tara. The ten hardest to fill jobs in the U.S. 2009: Web. http://www.forbes.com/2009/06/03/hardjobs-fill-leadership-careers-employment.html

48. Wirt, John, Choy, Susan, Rooney, Patrick, Provasnik, Stephen, Sen, Anindiya, and Tobin, Richard. Washington, D.C.: National Center for Education Statistics. 29 Sept. 29, 2008: Web. http://nces.ed.gov/programs/coe/2004/pdf/31_2004.pdf

49. Women in Engineering ProActive Network. Engaging America's Intellectual Talent: The Status of Women and Minorities in Engineering. 18 September 18, 2011: Web. http://www.wepanknowledgecenter.org

50. Wulf, William A., "Diversity in engineering." The Bridge, 28.4 (1998): Web: http://www.nae.edu/Publications/Bridge/CompetitiveMaterialsandSolutions/DiversityinEngineering.aspx

51. Zhang, Giuli, Anderson, Tim, Ohland, Matthew, Carter, Rufus and Thorndyke, Brian. "Identifying factors influencing engineering student graduation and retention: a longitudinal and cross-institutional study." Journal of Engineering Education, 93.4, (2004): 313-320. Print. 